of the business community for funds for management education which would include their share of the needs of the two schools. In pledging full support to the universities concerned, he added that the Government did not in any way wish to imply that management studies, whether at universities, colleges of advanced technology and technical colleges or other institutions, would no longer be needed or were to take a second place. Raising the quality of management at all levels called for steady development of all work now proceeding in the various parts of Britain's educational system as well as for the establishment of these two new schools.

Replying to questions, Mr. Hogg said that he did not think that the Trade Union movement had yet been brought formally into consultation, although it was very closely associated with the whole problem of management studies in technical colleges and colleges of advanced technology as well as the universities. Two separate courses were to be held at these schools, one a one-year course for two hundred postgraduates, and the other a twonty-week course or a half-year course for a hundred post-experience students. He agreed that business training was needed at several levels in all parts of Britain and that Scotland must not bo loft out of that. He endorsed all that had been said about the importance of professional bodies in business studies generally. A parallel statement was made in the House of Lords on the same day.

\section{Desalination Research in Britain}

IN a written answer in the House of Commons on May 15, Sir Edward Boyle stated that the Department of Scientific and Industrial Research had constituted a desalination research committee to advise how it could most usefully assist British industry in the general field of desalination research and development. The committee, of which Dr. L. Grunberg was chairman, included Prof. R. S. Silver and Dr. A. Hitchcock, and was at present considering an application for assistance in the distillation field. It had also been informed of the industrial interest in freezing and reverse osmosis. The committee had a continuing function in advising the department and was unlikely to render specific reports. The International Atomic Energy Authority had convened two panel meetings on the use of nuclear energy in salt. water conversion, at which the United Kingdom was represented by Prof. Silver and Dr. Hitchcock.

\section{Page Charges for Scientific Journals}

The Council of the Royal Society of London has had under consideration the practice of charging by the page for the publication of papers in scientific journals. The Council was advised in this connexion by its Scientific Information Committee and made the following recommendation on the adoption of this prectice in the United Kis gdom:

"In the United Kir gdom the authorities traditionally responsible for the bulk of the publication of original scientific work have been the scientific societies. These societies by maintaining the highest standards are rendering an outstanding service to the scientific community and discharging an important public function. The custody of the standards of publication of original work should remain in the hands of the scientific societies with their well-tried and proven methods evolved ovor many years. These methods ensure that the quality of the scientific content of the papers, properly assessed by expert referees, is the criterion of acceptance for publication. Experience in recent times has shown that the major publishing societies, by using up-to-date methods, need not be financially embarrassed in their publication of original work.

"In such circumstances the scientific societies in this country should retain their complete independence of factors other than scientific merit in relation to primary publication. It is considered that the introduction of page charges as a general principle might impair this independence and could lead to a fundamental change in the pattern of publication practice in this country. In the event of a scientific society being unable to finance its publications satisfactorily from the normal means of membership subscriptions and sales to non-members it is considered preferable that financial assistance should be made available through one independent co-ordinating body. The Royal Society performs this function on the advice of its Scientific Publications Board and is willing to consider means of assisting scientific societies to overcome difficulties. The Council of the Royal Society is of the opinion that the introduction of page charges for journals published by scientific societies in the. United Kir gdom would be against the best interests of the promotion of natural knowledge in this country and strongly recommends that such a practice shall not be adopted by British scientific societies."

\section{The Ciba Foundation}

The annual report for 1963 of the Ciba Foundation records a total of 947 visitors from 44 countries staying at the Foundation (Pp. 70. London: The Ciba Foundation, 1964). Many of the visitors participated in the Foundation's programme of six international conferences, three study groups, eleven discussion meetings, six sessions of scientific films, three dinners for scientific discussion and four guest conferences, or in some sixty meetings convened at the Foundation by other organizations and socioties. The Foundation's Annual Lecture was given by Prof. V. Ramalingaswami on "Perspectives in Protein Malnutrition", and the annual Ageing Research Lecture, by Dr. R. L. Boucek, of Miami. Details of the conferences, study groups, discussion meetings, etc., are given in the report, which also includes a list of publications, and of accessions to the library.

\section{Research : Science and Technology}

The remarkable feature of the careers book for prospective science and technology students, published recently under the above title, is that it was produced by two eighteon-year-old schoolboys from Marlborough College. The book was compiled as an entry for a Trevelyan Scholarship by A. G. R. Birtwell and J. G. T. Thornton and, inter alia, contains articles on "Science and the Sixth Former", by Sir Harry Melville; "Technology in the Oil Industry", by A. L. Dowding; "Electrical Engineering", by B. E. Ness; "Research in the Steel Industry", by M. Atkinson, "Opportunities in Agriculture", by F. H. Garner; "Frontiers of Atomic Power", by Dr. R. M. Longstaff; "Research in Medicine", by Dr. P. B. Medawar; "Microwave Spectroscopy", by Prof. D. J. E. Ingram; "Research in Psychiatry", by Felix Brown; and "The Colleges of Advanced Technology", by Sir Peter Venables. All profits from the sale of this ninety-six page booklet are being devoted to Oxfam and Cancer Research. Copies are available from Messrs. A. G. R. Birtwell and J. G. T. Thornton, Marlborough College, Marlborough, Wilts., price $2 s .6 d$.

\section{General Classification Schemes}

UNDER the title Some Problems of a General Classification Scheme, the Library Association has issued a report of a conference held in London in June 1963 (Pp. 47. London: The Library Association, 1964. 10s.; Library Association members $7 s, 6 d$.). The conference was organized by the Classification Research Group at the request of the Association and was supported by a grant from the NATO Scientific Research Fund. Mr. D. J. Foskett explains how the conference arose out of a discussion in classification problems at the Reference and Special Libraries Section Conference in 1957 and from a recommendation in the report Increasing the Effectiveness of Western Science (Nature, 189, 339; 1961). The remaining papers are: R. A. Fairthorne's "Browsing Schemes and 